\title{
Partners or Rivals? Norway and the European Union in the High North
}

\author{
Andreas Østhagen and Andreas Raspotnik
}

\section{1 \\ Introduction}

Ever since the European Union (EU) became actively engaged in Arctic affairs, its related relationship with Norway-as its immediate Arctic/northern neighbour - can be characterised as paradoxical. Although Norway has pro-actively worked to get the EU more involved in Arctic (governance) issues, it has, from the European Commission's (the Commission) first Communication on Arctic issues in 2008, ${ }^{1}$ been sceptical of various policy and legal steps taken by the EU. As a matter of fact, this apparent "enthusiasm and scepticism", illustrates much of Norway's relationship with the EU; not only in the Arctic, but also in the overarching relationship between these two international actors.

Norway's liaison with the EU can generally be characterised as not 'in' but neither really 'out' of the EU. Although Norway is not a EU Member State, it is politically and economically closely connected to the Union via a broad range of agreements and other forms of cooperation. ${ }^{2}$ A member of the European Economic Area (EEA) since 1994 — when the bid for EU membership failed for a second time-Norway adheres to the majority of European legislative acts. Accordingly, Norway can be characterised as the "most integrated outsider" to the Union. ${ }^{3}$ And yet, in Norway, the EU is often portrayed as something far removed from its political processes, separated in the domain of foreign policy.

* Andreas Østhagen, Research Fellow, Norwegian Institute for Defence Studies, Oslo, Norway and PhD candidate, Liu Institute for Global Issues, University of British Columbia, Canada.

** Andreas Raspotnik, Senior Fellow, The Arctic Institute, Washington DC, United States.

1 Commission of the European Communities, 'The European Union and the Arctic Region', сом (2008) 763 .

2 K. Keil and A. Raspotnik, 'The European Union's Gateways to the Arctic' (2014) 19(1) European Foreign Affairs Review 101, 104.

3 Christophe Hillion, 'Integrating an Outsider: An EU Perspective on Relations with Norway' (2011) Europautredningen Rapport \#16 8. 
The Arctic, however, is closely linked to Norwegian national identity. As the region saw a surge in global attention almost a decade ago, Norway found itself faced with the Eu pursuing a more active role in what constitute 'core' interests for Norway in a wide range of policy areas. Ever since this particular regional activeness by the Union, the Norway-EU relationship has been challenging. Norway is grappling with the desire to get European engagement in Arctic affairs, while simultaneously safeguarding its sovereign rights and interests.

This Chapter investigates the complex and ambiguous relationship between Norway and the EU. It asks: Why does the Arctic relationship between Norway and the EU take on these paradoxical traits? Which conditional elements can explain Norway's ambivalence towards the EU in Arctic/northern affairs?

We will in turn argue that it is somewhat futile to separate the Arctic domain from the overarching Norway-EU relationship. Although useful for policymakers in the Norwegian Ministry of Foreign Affairs (MFA), such separation is a symbolic action that does not help explain the larger trends in the relationship between the Scandinavian country and the politico-economic union of (currently) 28 Member States. At the same time, only discussing Norway-EU relations omits an essential and often neglected domestic actor in Norway, namely the Norwegian Arctic itself. Hence, we need to recognise how the EU's Arctic quest relates not only to Norway and the Arctic as a foreign policy domain, but also to the northern parts of Norway and the Arctic as a domain linked to regional and economic development.

We examine these relationships in the light of three examples:(1) the discussions embedded in the broader Arctic governance theme, (2) the EU's impact on, and efforts to regulate, industrial policies of relevance to the Norwegian Arctic, and finally (3) regional development and the indigenous peoples' aspects of the Union's Arctic engagement. In sum, studying these domains will help to answer the questions laid out above. However, before scrutinising how the Arctic has figured in this ambiguous relationship, we first need to briefly conceptualise the larger context of Norway's liaison with the EU. Afterwards, we will examine the EU's Arctic relationship with Norway, through each of the illustrations described, before returning to the questions posed above.

\section{Norway and the EU: It's Complicated}

Norway's relationship with the EU can-at best-be characterised as ambiguous. By 2017, the Norwegian government had twice initiated the process of negotiating membership terms, only for the prospect of membership to be rejected by national popular vote at the final stage. This section elaborates on 
the broader relationship between these two actors, in which the Arctic is only one of many policy issues, albeit one of growing importance.

\subsection{Rejecting the $\mathrm{E} U$, Twice}

In 1972, with Denmark, Ireland and the United Kingdom seeking European Community (EC) (the European Union's predecessor) membership, Norwegian politicians surmised that it would serve the country's interests to join the Union as well. Labour Prime Minister Trygve Bratteli strongly argued for Norwegian accession, motivated by both economic and security interests. ${ }^{4}$ Yet, when the choice was given to the Norwegian citizens, $53.5 \%$ voted against membership, while $46.5 \%$ were in favour of it. Norway consequently chose to stay out, as the EC went from its initial six founding members to a total of nine member states. After the end of the Cold War and the (re)-appearance of a range of new States across Central and Eastern Europe in early 1990s, accession talks were initiated to bring formerly non-aligned Austria, Finland and Sweden into the EU. It was at this point that Norwegian politicians again deemed it imperative for Norway not to be left behind again. Then Labour Prime Minister Gro Harlem Brundtland actively tried to persuade the Norwegian population using the same argument as in 1972 concerning economic benefits, but also emphasising the democratic imperative of joining the Union. ${ }^{5}$ It was thought that the effect of the Finnish and Swedish population having voted 'yes' a few months earlier, with $56.9 \%$ and $52.3 \%$ respectively in favour of EU membership, would constitute the final rationale for Norway to join the EC. Norway could not afford to stand-alone when all of its Nordic neighbours apart from Iceland (Denmark joined in 1973) had joined. The referendum in 1994, however, produced almost the exact same result as 22 years earlier, namely $52.2 \%$ against and $47.8 \%$ in favour of the EC membership.

Albeit difficult to sum up, an extensive body of research has pointed to some factors about why Norway decided to stay out of the Union. One essential argument is that Norwegian geography and political structures determined the two negative outcomes. Yes-votes are more likely to come from the urban centres and capitals, but in Norway counties and local governments are conceived as more autonomous than their Finnish and Swedish counterpart, so

4 N.R.K. Skole, 'Trygve Bratteli Om EEC' (1967) <http://nrk.no/skole/klippdetalj?topic=nrk: klipp/507187> accessed 1 March 2016.

5 Gro Harlem Brundtland, Madam Prime Minister: A Life in Power and Politics (Farrar, Straus and Giroux 2002) 311-317. 
it lacks the urban centres and capitals to pull the vote towards yes. ${ }^{6} \mathrm{~A}$ second argument is concerned with the cost-benefit analysis of membership that each citizen performs before voting, where the former so far has outweighed the latter. This was in particular due to the EC's poor track record in a few policy areas key to Norway, such as fisheries and agriculture. ${ }^{7}$ Finally, the idea, or conceptualisation, of the $\mathrm{EU}$ as a liberal 'project' intent on eroding the arguably successful Norwegian social democratic model, is frequently used in antimembership campaigns. ${ }^{8}$ The influence of such ideas also ties into the argument that the no-votes are driven by an underlying apprehension concerning the Union's supranational development, eventually eroding national StateWestphalian - sovereignty. Assimilated under Danish rule for four centuries (1524-1814), Norway only became an independent State in 1814, and truly autonomous after the dissolution with the imposed personal union with Sweden in 1905. Therefore, as the story goes, the EU constitutes a threat to a relatively 'young' Norwegian State, resembling an all too familiar oppressive dominator to Norwegian citizens. ${ }^{9}$

It is not this Chapter's purpose to question and validate the accurateness of the outlined arguments. However, in the context of Norway's Arctic relationship with the EU, it is important to recognise and understand why Norway twice has chosen to remain outside the Union and looks likely to remain outside in the foreseeable future.

\subsection{Current Relationship}

Norway did not sever ties with the EU after the referendum in 1994. Instead, Norway - together with Austria, Finland, Iceland, Liechtenstein and Sweden

6 Clive Archer, Norway Outside the European Union: Norway and European Integration from 1994 to 2004 (Routledge 2005); Ingrid Sogner and Clive Archer, 'Norway and Europe: 1972 and Now' (1995) 33(3) Journal of Common Market Studies 389; Norges offentlige utredninger (NOU), 'Utenfor Og Innenfor: Norges Avtaler Med EU' (Utenriksdepartementet 2012) 2012:2 2.

7 Stephan Kux and Ulf Sverdrup, 'Fuzzy Borders and Adaptive Outsiders: Norway, Switzerland and the EU' (2000) 22(3) Journal of European Integration; Espen Barth Eide, 'We Pay, but Have No Say: That's the Reality of Norway's Relationship with the EU' The Guardian (27 October 2015) <http://www.theguardian.com/commentisfree/2015/oct/27/norway-eu-reality-uk-votersseduced-by-norwegian-model> accessed 1 March 2016; Archer, n. 6 above.

8 Ibid.

9 Heming Olaussen, 'Fortsatt Nei Til EU' Aftenposten (27 November 2014) <http://www.aften posten.no/meninger/debatt/Fortsatt-nei-til-EU-7802845.html> accessed 1 March 2016; Tor Bjørklund, Mot Strømmen: Kampen Mot EF 1961-1972 (Universitetsforlaget 1982); Sieglinde Gstöhl, Reluctant Europeans: Norway, Sweden, and Switzerland in the Process of Integration (Lynne Rienner Publishers Inc 2002) 60. 
and the then 12 EC member states-signed the European Economic Area (EEA) agreement, which eventually entered into force in 1994. The EEA was initially described as a staging platform for Eu membership. ${ }^{10}$ Yet, for Norway, the agreement has come to constitute a permanent affiliation with the $\mathrm{EU}$, standing outside the Union while simultaneously being inside the economic area. ${ }^{11}$ Accordingly, Norwegian politicians have described the EEA as the best and the worst of both worlds. ${ }^{12}$

The agreement provides access to the EU's single market, but without the benefits, participatory or democratic rights that come with EU membership. Some policy areas are also specifically excluded, such as common fisheries and agriculture policies, justice and home affairs, foreign policy and monetary coordination. The EEA implies that Norway has to accept and implement all EU legislation relating to the economic area without an official vote in the formation of the legislation. Nevertheless, it grants Norway a formal veto mechanism, in addition to several consultative mechanisms. Critiques argue that these measures do little to remedy the democratic deficit inherent in this set-up. ${ }^{13}$ As a matter of fact, a recent study concluded that Norway only issued reservations to 17 out of more than 6000 legal acts with EEA relevance. ${ }^{14}$ Additionally, as European integration has expanded far beyond the realms of an economic area, Norway now participates in a number of other institutional constructions and political or financial commitments. For example, Norway is a member of the Schengen area, participates in EU programmes and actions, and contributes financially to economic and social cohesion in Europe. ${ }^{15}$

Debate on the potential for Norwegian membership of the EU has, since 1994, been a somewhat dismal affair, and it is currently not high on the political or academic agenda. ${ }^{16}$ Often trapped in a starch dichotomy between the 'yes' and the 'no' interest groups, uncertainty about what membership would actually entail has left the debate dominated by speculation and scare tactics. Similarly, as the EU has increased tremendously both in terms of Member

\footnotetext{
$10 \quad$ Brundtland, n. 5 above, 293-309.

11 Norges offentlige utredninger (NOU) 19.

12 Martin J. Kristofferesen, 'Eøs Var En Avtale Som Egentlig Ingen Ville Ha' Nationen (11 October 2015) <http://www.nationen.no/politikk/eas-var-en-avtale-som-ingen-villeha/> accessed 1 March 2o16; Olaussen.

13 Ibid.

14 Norges offentlige utredninger (NOU) 20.

15 Hillion, $\mathrm{n} .3$ above, 9 .

16 Keil and Raspotnik, n. 2 above, 104.
} 
States (from 12 in 1994 to 28 in 2016) and policy domains, ${ }^{17}$ the ability to understand the full range of the Eu's machinery is a challenge for Member States, let alone Norway as a non-member. In turn, as Norway experienced an economic boom from the 200os onwards that even surpassed its European partners, the prospects of an eventual EU membership dimmed. In 2014, polls responded that only $16.8 \%$ of Norwegians supported a membership bid, whereas $74 \%$ were against and $9.2 \%$ were undecided. ${ }^{18}$ With the subsequent crises over the Euro and migration engulfing EU politics, membership has not become more popular. At the same time, Norway's economy has been sheltered by a relatively large public sector fuelled by natural resource industries, in tandem with financial regulations. ${ }^{19}$ With Iceland's recent failed bid for membership in mind, ${ }^{20}$ a possible (inevitable?) economic downfall for Norway might make the prospects of EU membership seem more appealing. Similarly, as the UK embarks on leaving the Union, proponents of a renegotiation of the EEA treaty perceive potential room for manoeuvre to secure a better deal. ${ }^{21}$

17 Simon Bulmer, Economic and Political Integration in Europe: Internal Dynamics and Global Context (Blackwell 1995); Desmond Dinan, Ever Closer Union? An Introduction to European Integration (4th edn, Palgrave Macmillan 2010).

18 'Nordmenn Har Aldri Vært Mer Mot EU' Dagens Nceringsliv (28 November 2014) <http:// www.dn.no/nyheter/politikkSamfunn/2014/11/28/0550/nordmenn-har-aldri-vrt-mermot-eu> accessed 1 March 2016.

19 Henrik Horjen, 'Mener Eurokrisen Seiler Forbi Norge' Aftenposten (13 June 2012) <http:// www.aftenposten.no/okonomi/Mener-eurokrisen-seiler-forbi-Norge-6848184.html> accessed 1 March 2016; Cecilie Langum Becker and Kari Vartdal Riise, 'Derfor Bommer Eurokrisen På Norge' Dagens Nceringsliv (4 September 2012) <http://www.dn.no/ nyheter/2012/o9/04/derfor-bommer-eurokrisen-pa-norge> accessed 1 March 2016. Iceland initiated accession discussions with the EU after a parliamentary vote in 2009, but then abandoned negotiations in 2013 and officially withdrew its application in 2015. The fisheries conflict regarding mackerel and herring was one of the motivating factors behind this decision, see inter alia Graham Avery, Alyson J.K. Bailes and Baldur Thorhallsson, 'Iceland's Application for European Union Membership' (2011) LXIV Studia Diplomatica 93; Alyson J.K. Bailes and Baldur Thorhallsson, 'Iceland and Europe: Drifting Further Apart?' (Finnish Institute of International Affairs (FIIA) 2013) FIIA Briefing Paper 139 <http://www.fiia.fi/assets/publications/bp139.pdf> accessed 1 January 2014; Minister for Foreign Affairs Iceland, 'Government Considers Iceland No Longer an EU Candidate (Reykjavík, 12 March 2015)' <http://www.mfa.is/media/gunnar-bragi/Bref-ESBENS-pdf.pdf >; Sigmar Arnarsson and Debra Justus, 'Changing Nature of Arctic Fisheries' in Adam Stępień, Timo Koivurova and Paula Kankaanpää (eds), Strategic Assessment of Development of the Arctic. Assessment conducted for the European Union (Arctic Centre, University of Lapland 2014) 64.

21 Kathrine Kleveland, 'EØS Er Bedre Enn EU' Dagbladet (4 November 2015) <http://www .dagbladet.no/2015/11/04/kultur/meninger/eos/storbritannia/kronikk/41796213/> accessed 1 March 2016; 'Sovereignty, Autonomy and Britain's Relationship with Europe' The 
For now, however, Norway and the Eu have come to a mutual understanding that arguably does not fully satisfy anyone. Norway contributes financiallythrough the so-called EEA (and Norway) grants ${ }^{22}$ - while also participating in EU policy implementation and the growing number of European-wide bodies and agencies, yet without allowing full integration and/or having direct decision-making participation. Espen Barth Eide, former Foreign Minister of Norway put it rather critically when stating "We pay, but have no say: that's the reality of Norway's relationship with the Eu". ${ }^{23}$ Although a number of Norway's policy areas are kept separate from the European market, it is important to note the extent to which EU legislation is incorporated - and even determinesNorwegian policy on everything from safety regulations to public ownership and state aid. ${ }^{24}$ Hence, it can be concluded that Norway is "mainly a rule-taker rather than a rule-shaper of European policies". 25

One aspect, however, of the Norway-EU relations that is often neglected in literature, is the degree to which Norway can assert informal influence in the EU policy-making process. Norway is, by most definitions, a State with limited (global) capacities and influence. Yet, this is not to discount that Norway has capabilities in certain domains, where the country's reputation, wealth and geography come into play. A disputed concept, the idea of the Eu's open decision-making procedures still enables a wide range of actors to participate in EU policy-making in Brussels. However, the key aspect here is participation. Many of the arenas where influence can be wielded and decisions are being made are informal, through lobbying procedures and public consultations. Norway did, eventually, awake to this new reality. Consequently, the Norwegian Delegation to the EU constitutes Norway's largest diplomatic mission, with over 60 employees. ${ }^{26}$ Similarly, a number of Norwegian stakeholders-ranging from regional representations to businesses-are present in Brussels, to monitor and potentially influence specific policy issues where they have key interests.

Guardian (24 February 2016) <http://www.theguardian.com/politics/2016/feb/24/sov ereignty-autonomy-and-britain-relationship-with-europe $>$ accessed 1 March 2016. On 23 June 2016, a majority of $51.89 \%$ of UK citizens voted to leave the European Union in a non-legally binding referendum, the so-called Brexit referendum.

For the financial period 2009-2014 Norway contributed €951.78 million of the overall $€ 993.50$ million, that supported 86 programmes in 16 countries in Europe, from environmental protection, climate change to human and social development issues, see $<$ http:// eeagrants.org/Who-we-are/EEA-Grants> accessed 20 November 2016.

Ibid.

24 See Norges offentlige utredninger (NOU).

25 Keil and Raspotnik, n. 2 above, 104.

26 The Norwegian Mission to the EU, see <http://www.eu-norway.org/> accessed 20 November 2016 . 
From an Arctic perspective and with the High North occupying centre state in Norwegian domestic policy, which is discussed in Section 2.3 below, Norway works to keep Arctic attention high in Brussels, aiming to lead E U Arctic debate and influence it from the outside. ${ }^{27}$

\subsection{The Norwegian Arctic}

Norway holds particular clout in the Arctic region, as it is one of only five coastal States (the Arctic Five or A5), and it has a considerable Arctic population and a key interest in the development of the region. In Norway, the Arctic is everything north of the Arctic Circle $\left(66^{\circ} 34 \mathrm{~N}\right)$, though there is arguably minimal variation between the immediate areas north and south of the circle. In the northern region, Norway borders Finland, Sweden and Russia. The Norwegian Arctic is separated into three counties (from south to north) of Nordland, Troms and Finnmark, often just termed North Norway, and the Svalbard Archipelago north of the Norwegian mainland. In sum, about 480,00o people inhabit these three counties and about 2,700 people reside on Svalbard. ${ }^{28}$ Although it is difficult to specify exactly, the Sámi population in Norway is approximately 40,000 to 50,000, and most of them live in North Norway. ${ }^{29}$ Albeit sparsely populated in a European context, the size of the population is relatively high compared to indigenous populations in the North American Arctic. ${ }^{30}$

In its foreign policy engagement, Norway distinguishes between the extreme Arctic (referring to the North Pole and the uninhabited areas in the so-called High Arctic) and the more hospitable and populated parts of North Norway

27 Interview conducted by Andreas Raspotnik with two representatives from the Norwegian MFA working on Arctic matters in Oslo on 24 April 2014. Accordingly, Wegge expounded the Norwegian policy influence in both the Commission's work on the Integrated Maritime Policy (IMP) and the first Communication on Arctic issues, see Njord Wegge, 'Small State, Maritime Great Power? Norway's Strategies for Influencing the Maritime Policy of the European Union' (2011) 35(3) Marine Policy 335; Njord Wegge, 'The EU and the Arctic: European Foreign Policy in the Making' (2012) 3(1) Arctic Review on Law and Politics 6.

28 Statistics Norway (SSB), 'Folkemengde Og Befolkningsendringar, 1. Januar 2016' (Folkemengde, 19 February 2016) <https://www.ssb.no/befolkning/statistikker/folkemengde/ aar-berekna/2015-12-17> accessed 1 March 2016.

29 Nordic Sami Institute, 'Hvor Mange Samer Er Det Egentlig...?' (On Sami statistics, 29 January 2008) <http://www.sami-statistics.info/default.asp?nc=2807\&id=110 > accessed 1 March 2016.

30 See Timothy Heleniak and Dimitry Bogoyavlensky, 'Arctic Populations and Migration', Arctic Human Development Report: Regional Processes and Global Linkages (Nordic Council of Ministers 2015). 
and Svalbard, deemed the 'High North' (nordområdene in Norwegian). ${ }^{31}$ It is essential to differentiate between the mainland and the Svalbard archipelago, while at the same time recognising that the latter is a part of the Kingdom of Norway. ${ }^{32}$ Norway was granted sovereignty over the Svalbard archipelago with the Svalbard Treaty, signed in 1920 in Paris and entered into force in $1925 \cdot{ }^{33}$ The Treaty stipulates that Norwegian sovereignty is, however, subject to certain conditions, e.g. limitations on Norway's ability to tax and use the islands for military purposes, by simultaneously assigning the right of access for commercial operations to nationals of all the contracting parties. ${ }^{34}$ Despite this early 2oth century diplomatic "package deal",35 diverging (legal) views exist with regard to the maritime zones beyond Svalbard's territorial sea and the question of whether or not the Treaty applies in these maritime areas. ${ }^{36}$ Although claiming to have a right to establish an exclusive economic zone (EEZ) around Svalbard, Norway has not yet chosen to make use of it. Instead it established a Fisheries Protection Zone (FPZ) in 1977, for the purpose of the conservation and management of marine living resources. ${ }^{37}$ What is clear, however, is that

31 Jonas Gahr Støre, 'The High North and the Arctic: The Norwegian Perspective' (2012) 2 The Arctic Herald 8; Leif Christian Jensen, 'Norway on a High in the North: A Discourse Analysis of Policy Framing' (University of Tromsø UIT 2012); Leif Christian Jensen and Geir Hønneland, 'Framing the High North: Public Discourses in Norway after 2000' (2011) 28(1) Acta Borealia 37, 44-52.

32 The Svalbard archipelago lies in the Barents Sea and includes all the islands situated between $74^{\circ}$ and $81^{\circ} \mathrm{N}$ and $10^{\circ} \mathrm{E}$ and $35^{\circ} \mathrm{E}$, inter alia Spitsbergen, Nordaustlandet, Edgeøya or Bjørnøya, with a total landmass of $62,400 \mathrm{~km}^{2}$.

33 Treaty concerning the Archipelago of Spitsbergen (signed 9 February 1920, entered into force 14 August 1925) 2 LTNS 7.

34 As of 4 December 2014, 42 states are parties to the Treaty, see $<$ http://emeritus.lovdata.no/ traktater/> accessed 20 November 2016.

35 D.H. Anderson, 'The Status Under International Law of the Maritime Areas Around Svalbard' (2009) 40(4) Ocean Development \& International Law 373, 374.

36 See Torbjørn Pedersen and Tore Henriksen, 'Svalbard's Maritime Zones: The End of Legal Uncertainty?' (2009) 24(1) The International Journal of Marine and Coastal Law 141; Robin Churchill and Geir Ulfstein, 'The Disputed Maritime Zones around Svalbard' in Myron H Nordquist, John Norton Moore and Thomas H Heidar (eds), Changes in the Arctic Environment and the Law of the Sea (Martinus Nijhoff Publishers 2010); Erik J Molenaar, 'Fisheries Regulation in the Maritime Zones of Svalbard' (2012) 27(1) The International Journal of Marine and Coastal Law 3; Andreas Raspotnik and Andreas Østhagen, 'From Seal Ban to Svalbard-The European Parliament Engages in Arctic Matters' (The Arctic Institute, 10 March 2014) <http://www.thearcticinstitute.org/from-seal-ban-to-svalbardeuropean/> accessed 11 March 2014.

Molenaar, n. 36 above, $14-15$. 
the EEA agreement does not apply to the archipelago of Svalbard pursuant to the EEA's protocol $40 .{ }^{38}$

Norway's engagement in Arctic affairs can be traced back to Jonas Gahr Støre's decision to place emphasis on the High North (in a Norwegian context) and the Arctic (in an international perspective), when he became Foreign Minister in 2005 as part of the 'red-green' government coalition. ${ }^{39}$ The elevation of the Arctic to the number one strategic foreign policy priority in 2005 also coincided with the failed arrest of the Russian trawler Elektron, turning Norway's attention towards maritime cooperation with Russia in the Barents Sea. With Russia's planting of a flag at the North Pole's seabed in 2007, worldwide attention turned towards the region and Støre made use of the opportunity to place emphasis on regional development domestically, and multilateral cooperation internationally, via arenas such as the Arctic Council (AC) and the Barents Euro-Arctic Council. Since 2005, Norwegian Arctic policy has-as most national Arctic policies have-revolved around vague concepts of 'sustainability', 'multilateral cooperation', surrounded by a distinct, at least implicit, sovereignty theme of 'our Arctic'.40 Ultimately the 'red-green' coalition was criticised for failing to deliver on their grand Arctic policy statements. ${ }^{41}$ However, the new conservative government that took office in 2013 has arguably changed little, and at times even seemed uninterested in following up Arctic policies set out by their predecessor.

In Norway, Arctic policy is predominantly coined in Oslo, hence south of the Arctic Circle, and led by the Norwegian MFA in cooperation with a range of other ministries. Inherently, a divide exists, as in any other Arctic State, between its foreign and regional policy commitments. Promoting the AC, multilateral cooperation and search and rescue agreements do not achieve much on a regional level (at least immediately). In a Norwegian unitary state structure, demands have been brought forward from the Arctic counties for more regional autonomy, or at least increased participation in national decision-

$38 \quad$ Keil and Raspotnik, n. 2 above, 104.

39 Between the Labour party (Arbeiderpartiet), Socialist Left Party (Sosialistisk Venstreparti) and Centre Party (Senterpartiet).

40 Leif Christian Jensen, Øystein Jensen and Svein Vigeland Rottem, 'Norwegian Foreign Policy in the High North: Energy, International Law and Security' (2011) 35 Atlantisch perspectief 1 ; Jo Inge Bekkevold and Kristine Offerdal, 'Norway's High North Policy and New Asian Stakeholders' (2014) 38(6) Strategic Analysis 825.

41 Asle Toje, 'Arktisk Nachspiel' Dagens Nceringsliv (1 March 2015) <http://www.dn.no/ meninger/debatt/2015/03/01/2057/Globalt/arktisk-nachspiel>accessed 1 March 2016. 
making relating to the Norwegian Arctic. ${ }^{42}$ Appeasement from Oslo takes the form of additional regional funds, investment in Arctic-specific services such as emergency response equipment, and enhancing the two universities in Bodø and Tromsø. The interests of those inhabiting the Norwegian north will arguably not always coincide, or even be impacted by, the Arctic foreign policy initiatives by Norway as a State.

It is in this juncture of domestic, regional and international elements that the Eu's Arctic policy engages, with the likely outcome that some friction appears. We now turn to some of these frictions and key interests, which interplay with both the state and regional level in Norway.

In the context of more EU attention placed on Arctic affairs, the Norwegian Arctic holds a particularly prominent role. In contrast to the Finish and Swedish Arctic territories, North Norway has access to the Arctic Ocean: a geographical fact that to a certain extent hampers the Union's Arctic endeavour. It is also more populous than its Nordic counterparts. While not a geographical part of EU territory, North Norway is more closely linked to the EU than any other non-EU Arctic areas, such as Alaska, the Canadian territories, the Russian Arctic regions and perhaps even Greenland. Moreover, North Norway is integrated in, and exports to, the EU common market, borders EU members Finland and Sweden, and is logistically connected to all major European cities.

In addition to the Norwegian Delegation to the EU, the three Arctic counties in Norway also have their own representation in Brussels. ${ }^{43}$ At one point the largest regional office amongst the Norwegian offices in spite of having the smallest population, their presence is legitimised through the very fact that the EU is actively engaging in the Arctic region. At the same time, the representation argues that there is an inherent lack of information concerning the Norwegian Arctic in the EU decision-making system in Brussels: "We find

\footnotetext{
42 Arne O Holm, 'Kommentar: Ikke En «jævla Nordlending»' High North News (25 May 2015) <http://www.highnorthnews.com/ikke-en-jaevla-nordlending/> accessed 1 March 2016; Miriam Stackpole Dahl, 'Nord-Norge Med Innspill Til EUs Arktis-Politikk' (Norwegian Government, 6 December 2012) <https://www.regjeringen.no/no/aktuelt/nord-norgemed-innspill-til-eus-arktis-p/id709356/> accessed 1 March 2016.

43 North Norway European Office <http://www.northnorway.org/> accessed 20 November 2016.
} 
that most bureaucrats in Brussels have very little knowledge of, and interest in, North Norway as such."44

Based on this conception of North Norway's relationship with the EU and the EU's Arctic policy engagement - as taking place on both a regional and a foreign policy level-there are some issues that help to explain Norway's ambivalent relations to the EU in the Arctic.

\subsection{Discussing Arctic Governance}

Increasing Arctic/High North awareness within the hallways of EU power in Brussels has appeared on the Norwegian agenda ever since the Union's development of an Integrated Maritime Policy (IMP), ${ }^{45}$ starting in 2005/2006. ${ }^{46}$ Eventually, creating a distinct Arctic understanding took place on a whole spectrum of policy areas, from environmental research, indigenous people's issues to defence and energy security. ${ }^{47}$ When the EU initially got engaged with Arctic issues, the mood quickly soured in Norway.

The European Parliament (EP) in 2008 suggested opening "international negotiations designed to lead to the adoption of an international treaty for the protection of the Arctic, inspired by the Antarctic Treaty" and aimed to cover, in particular, "the unpopulated and unclaimed area at the centre of the Arctic Ocean". ${ }^{48}$ Subsequently, extensive deliberation in both the Commission (see its first Communication on The European Union and the Arctic Region $)^{49}$ and again the EP on a 'lack of governance' in the region initially caused outcry from Norwegian media and politicians. ${ }^{50}$ Although both the Commission and

44 Trond Haukanes, Director North Norway European Office; Interview conducted by Andreas Østhagen on 2 February 2016.

45 Commission of the European Communities, 'An Integrated Maritime Policy for the European Union', сом (2007) 575.

46 Kristine Offerdal, 'Arctic Energy in Eu Policy: Arbitrary Interest in the Norwegian High North' (2010) 63(1) Arctic 30; Kristine Offerdal, 'The EU in the Arctic: In Pursuit of Legitimacy and Influence' (2011) 66(4) International Journal 861; Wegge, 'The EU and the Arctic: European Foreign Policy in the Making', n. 27 above.

47 Kristine Offerdal, 'Norge, Nordområdene Og EU' (2011) Europautredningen Rapport \#20.

48 European Parliament, 'Resolution of 9 October 2008 on Arctic Governance (P6_TA (2008) 0474)' 15 .

49 Commission of the European Communities, n. 1 above.

50 Andreas Østhagen, 'The European Union-An Arctic Actor?' (2013) 15(2) Journal of Military and Strategic Studies 71; Raspotnik and Østhagen, 'From Seal Ban to SvalbardThe European Parliament Engages in Arctic Matters', n. 36 above; Andreas Raspotnik and Andreas Østhagen, 'To Svalbard and Beyond-The European Parliament Is Back on Its 
the EP have since then moderated such views, questions related to governance have at times appeared in Arctic-related debates in Brussels.

For example, one study conducted on behalf of the then Member of the European Parliament (MEP) Diana Wallis created some 'EU-Arctic' turmoil in Norway. The commissioned analysis examined the robustness of the legal framework concerning the Svalbard Treaty. ${ }^{51}$ Although the study only featured the opinion of one MEP out of 751 , some Norwegian media reacted as if the EU had threatened Norway, prompting headlines such as: 'The EU challenges Norwegian Svalbard policy'52 The Norwegian Government quickly responded with the legal justifications needed for the Treaty and made clear that under no circumstances would a re-negotiation be considered. ${ }^{53}$ The EU's interest in the Arctic was perceived as a threat to Norway when, in reality, the friction stemmed from a lack of knowledge about the very role and intentions of the EP and its representatives, respectively.

In general, a tendency seems to exist in Norway to portray the EU as one coherent actor, which often threatens Norwegian interests. The complexity of the multiple interests among 28 Member States and numerous political factions and parties are rather neglected. Particularly when scrutinising the EU institutional policy output, it is necessary to distinguish between the different voices of the Commission, Council of the European Union, European External Action Service (EEAS) and EP, respectively, and their actual impact on the policy process. ${ }^{54}$ In this vein one also has to understand an EP debate in February 2014 with some MEPs discussing the legality of the Norwegian interpretation of the Svalbard Treaty, enquiring whether the EU accepts the FPZ surrounding the archipelago. Although the EU acknowledges Norway's practice of the FPZ on the conditions that it is enforced in a non-discriminatory manner

Arctic Track' (The Arctic Institute, 17 March 2014) <http://www.thearcticinstitute.org/ to-svalbard-and-beyond-european/> accessed 18 March 2014.

51 Diana Wallis and Stewart Arnold, 'The Spitsbergen Treaty: Multilateral Governance in the Arctic' (2011) 1 <http://dianawallis.org.uk/en/document/spitsbergen-treaty-booklet.pdf> accessed 10 October 2012.

$5^{2}$ 'Norge I Skvis Om Svalbard' Adresseavisen (1 November 2011) <http://www.adressa.no/ meninger/article1719680.ece> accessed 1 March 2016; 'EU Utfordrer Norsk SvalbardPolitikk' Bladet Vesterålen (27 October 2011) <http://www.blv.no/ledere/eu-utfordrernorsk-svalbard-politikk/s/1-1175899-5784300> accessed 1 March 2016.

53 Andreas Østhagen, 'Debating the EU's Role in the Arctic: A Report from Brussels' The Arctic Institute (19 October 2011) <http://www.thearcticinstitute.org/european-arcticambiguity/> accessed 28 October 2012.

54 Raspotnik and Østhagen, 'To Svalbard and Beyond—The European Parliament Is Back on Its Arctic Track', n. 50 above. 
and respected by all interested parties, some Norwegian media critically covered the MEPs' endeavour. ${ }^{55}$ This particular lack of understanding of the EU policy-making system can be traced back to Norway's ambiguous relationship to the Union at large. As both an outsider and an insider (see Section 2 above), the public's interest in internal EU affairs is limited. Had Norway been a full EU Member State and had its own MEPs, some of these debates might have been curtailed by more accurate descriptions from the media and national politicians. ${ }^{56}$

\subsection{Regulating Arctic Offshore Oil and Gas Development}

The EU-due to the EEA-plays a varying but significant role in industrial development in the Norwegian Arctic, ${ }^{57}$ with several mechanisms and/or policies having both direct and indirect effects on regional oil and gas developments, mining and maritime transportation activities. ${ }^{58}$ An example of the Union's role creating Norwegian Arctic turmoil is the contentious debate surrounding the Commission's proposal to introduce a regulation on the safety of offshore oil and gas exploration in 2012. Some MEPs also tried to push for a moratorium on Arctic drilling during the proposal phase. ${ }^{59}$ Although

55 Terje Jensen, 'Stiller Spørsmål Ved Norsk Suverenitet I Vernesonen' Fiskeribladetfiskaren (3 March 2014); Eva Aalberg Undheim, 'Såg Ikkje Grunn Til Kritikk Mot Noreg' Nationen (1 March 2014) <http://www.nationen.no/eu/sag-ikkje-grunn-til-kritikk-mot-noreg/> accessed 5 March 2014; Raspotnik and Østhagen, 'From Seal Ban to Svalbard-The European Parliament Engages in Arctic Matters', n. 36 above; Molenaar, n. 36 above.

$5^{6}$ However, surveying EU-related debates in various member states over recent years, such a conclusion is by no means naturally guaranteed.

57 In this context we have chosen to disregard the debate on fisheries. Norway's fisheries policy is excluded from the EEA agreement. Yet, much can be said about EU/Norway relations in this domain, where the EU serves as both the largest market and a regulator in terms of setting market requirements and standards. For the Norwegian Arctic, fisheries are especially crucial, from both a social and an economical perspective. However, this Chapter focuses on other, arguably more directly linked, policy domains only. For related analysis that covered to some extent Norway's relationship with the EU in the domain of fisheries, see inter alia Bettina Rudloff, 'The EU as Fishing Actor in the Arctic: Stocktaking of Institutional Involvement and Existing Conflicts' (Stiftung Wissenschaft und Politik (SWP) 2010) SWP Working Paper FG 2, 2010/02 <http://www.swp-berlin.org/fileadmin/ contents/products/arbeitspapiere/Rff_WP_2010_02_ks.pdf> accessed 3 April 2012; Timo Koivurova and others, 'The Present and Future Competence of the European Union in the Arctic' (2012) 48(4) Polar Record 361.

$5^{8}$ However, mechanisms/policies related to energy exploration and exploitation do in principle not extend to the EEA and hence do not per se affect Norway, see ibid., 366 .

59 As observed by Andreas Raspotnik during attendances of meetings of the EP's Committees on Environment, Public Health and Food Safety (10 July 2012) and Industry, Research and Energy (11 July 2012), respectively. 
the Arctic was only mentioned twice in the 56-page draft document from the Commission's Directorate-General Energy, MEPs from the EU's environment committee proposed to re-write the related sections, adding a paragraph to request a halt in oil and gas drilling in the region. ${ }^{60}$ This demand was not added to the final directive based on the simple fact that the Union does not have (and for the foreseeable future will not have) legal jurisdiction over Norwegian Arctic waters. ${ }^{61}$ Nevertheless, with the directive having EEA relevance, the Commission's initiative prompted debate in Norway and led again to a public outcry. ${ }^{62}$

Norway regarded these actions as a direct threat to its interests in Arctic offshore development. As with the rest of the Arctic, attention turned towards the potential of Arctic industries in the north of Norway at the beginning of the new millennium with the Barents Sea being perceived as a new global frontier for oil and gas development. Since 1979, seismic activity and exploratory drillings have been taking place in the Barents Sea, with over a hundred wells drilled. Yet, in spite of substantial discoveries, only two producing fields-Statoil's Snøhvit and ENI's Goliat—exist with ENI just starting to produce oil from the Goliat field in March 2016. ${ }^{63}$ In general, low oil and gas prices and, equally important, a continuing lack of political commitment in Europe concerning Arctic hydrocarbon resources have halted further development. ${ }^{64}$

6o Andreas Østhagen, 'The EU and The Arctic: A Never Ending Story' (The Arctic Institute, 13 September 2012) <http://www.thearcticinstitute.org/eu-and-arctic-never-ending-story/> accessed 14 September 2012.

61 Arthur Neslen, 'Europe Rejects Ban on Arctic Oil Drilling' The Guardian (10 October 2012) $<$ http://www.theguardian.com/environment/2012/oct/10/europe-rejects-ban-arctic-oildrilling $>$ accessed 31 May 2013.

62 Thomas Nilsen, 'Norway: "EU Has No Jurisdiction in the Arctic"' BarentsObserver (3 October 2012) <http://barentsobserver.com/en/energy/norway-eu-has-no-jurisdictionarctic-03-10 $>$ accessed 28 October 2012.

63 Ellen Kongsnes, 'Goliat-Oppstart Utsatt Nok En Gang' Stavanger Aftenblad (1 March 2016) <http://www.aftenbladet.no/energi/Goliat-oppstart-utsatt-nok-en-gang-3880857.html> accessed 1 March 2016; Thomas Nilsen, 'First Barents Oil Production Starts Today' The Independent Barents Observer (13 March 2016) <http://thebarentsobserver.com/industry/ 2016/o3/first-barents-oil-production-has-started > accessed 14 March 2016.

64 Andreas Raspotnik, 'Is the European Union Missing Another Window of Opportunity for Arctic Energy Resources?' (The Arctic Institute, 5 December 2011) <http://www.thearctic institute.org/european-union-missing-energy-window/> accessed 6 December 2011; Henrik Stolen, Gwladys Fouche and Joachim Dagenborg, 'Norway's Rising Oil Costs Hit Arctic Output Hopes' Reuters us (16 January 2014) < http://www.reuters.com/article/

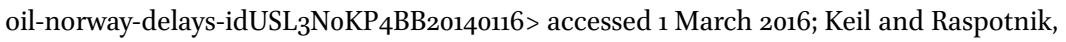
n. 2 above. 
In order to raise public awareness of the Norwegian Arctic energy and its importance for the EU's energy security, three Norwegian government ministers drafted a joint letter to Miguel Arias Cañete, the European Commissioner for Climate Action and Energy in January 2016. The ministers asked for a "clear message from the Commission that natural gas remains important for the EU's energy mix". A related European statement would be a "welcome signal" for Norwegian investment in exploiting the untapped gas resources in the Barents Sea. ${ }^{65}$ Adding to this, Norway's Petroleum and Energy Minister Tord Lien emphasised that a clear signal from the Union could also boost the case for an extended pipeline system from and to the Barents Sea. It currently stops more or less at the Arctic Circle. ${ }^{66}$

Although the EU and its Member States, respectively, are highly dependent on energy imports, its approach to tackle energy shortcuts is incoherent. Some States favour coal and nuclear power, others pay more attention to natural gas. Additionally, strong environmental groups in Europe oppose Norway's proclaimed 'green' gas and are in favour of renewable energy. ${ }^{67}$ In sum, despite the potential of the Barents Sea, the future of the Norway-EU energy outlook is anything but straightforward.

\subsection{Regional Development and the Sámi}

A third area of both influence and contention between Norway and the EU in the Arctic relates directly to regional development in North Norway. From a regional-financial perspective, the EU covers the Norwegian Arctic via its regional policy. The basic aim of the Eu's economic, social and territorial cohesion policy is to reduce disparities between the varying levels of development in different European regions. Accordingly, and with regard to the European north in general, the Treaty on the Functioning of the European Union (TFEU) stipulates that "particular attention shall be paid to (...) regions which suffer from severe and permanent natural or demographic handicaps such as the northernmost regions with very low population density (...)" (TFEU, Article

65 Norwegian Ministry of Petroleum and Energy, Norwegian Ministry of Climate and Environment and Norwegian Ministry of Foreign Affairs, 'Letter to EU Commissioner Miguel Arias Cañete' <https://www.regjeringen.no/contentassets/9ee937288b7c466bao 62f6eo23d8094b/letter_aspaker-helgesenlien-canete_29.1.2016.pdf> accessed 29 February 2016.

66 Jonas Cho Walsgard and Mikael Holter, 'Norway Says EU Gas Signals Strengthen Case for Arctic Pipeline' Bloomberg (12 February 2016) <http://uk.reuters.com/article/eu-norwaygas-idUKL8N15K1NU> accessed 1 March 2016.

67 Christian Oliver, 'Norway Urges EU Assurances on Gas Output' Financial Times (30 November 2015) <http://www.ft.com/cms/s/o/b74ad666-9526-11e5-8389-7c9ccf83dceb .html\#axzz41wwrOhGU> accessed 1 March 2016. 
174). ${ }^{68}$ In particular, the focus has been on three related funds- the European Regional Development Fund (ERDF), the European Social Fund and the Cohesion Fund - and some programmes covered by these funds, e.g. Interreg Nord, Botnia-Atlantica and/or the Northern Periphery Programme. For the new financial period-2014-2020 - the latter was even re-named the Northern Periphery and Arctic Programme, aiming to add a distinct Arctic-regional development level to the EU's Arctic policy as well as to national Arctic policies of the Union's Member States. ${ }^{69}$

Although there is relatively little difference between the Arctic and nonArctic communities in Norway, some traits have historically been more prominent in the north. Given the region's sparse population, vast distances, natural geographic barriers and dependency on traditional subsistence (fisheries, reindeer herding and agriculture), the northern counties have historically been poorer (as based on the gross domestic product per capita) than the rest of Norway. As the Norwegian welfare state grew after the Second World War, the north was targeted with regional development funds to help the region overcome barriers that did not exist in the south, such as sparse population, harsh climate and long distances to markets. Today, a system of differentiated employer's social security tax is meant to improve the conditions of operating businesses in the north, as the region enjoys lower tax levels. Similarly, both Finnmark and parts of Troms county have — since 1990 — had a lower income tax, return of student loans and a higher rate of child support.

In recent years, however, North Norway has been experiencing relatively high economic development. In addition to the oil-boom, the region's emphasis on seafood and fisheries, industrial products and tourism has helped spur this growth. ${ }^{70}$ Former Norwegian Foreign Minister Støre now depicts the future of the High North as one that turns away from a 'black'-hydrocarbon resource-economy to a 'blue' economy, which is based on Norway's leadership in the fields of maritime/ocean knowledge and renewable energy, like hydropower and wind. ${ }^{71}$ It is assumed that renewable energy production in

68 Consolidated Version of the Treaty on the Functioning of the European Union, 2012. Official Journal C 326, 26 October 2012.

69 European Commission, 'Northern Periphery and Arctic' (10 January 2015) <http://ec.europa .eu/regional_policy/en/atlas/programmes/2014-2020/UnitedKingdom/2014tc16rftnoo4> accessed 8 June 2015 .

70 Elise Holdal, 'Forventer Høyere Vekst I Nord-Norge Enn I Resten Av Landet' NRK (5 May 2015) <http://www.nrk.no/troms/forventer-hoyere-vekst-i-nord-norge-enn-i-restenav-landet-1.12344711> accessed 1 March 2016.

71 Ingrid A Medby, 'From Black Gold to a Blue Economy?' (The Arctic Institute, 26 November 2015) <http://www.thearcticinstitute.org/from-black-gold-to-a-blue-economy/> accessed 1 March 2016. 
the Norwegian Arctic, with an already produced regional power surplus and high theoretical potentials, could have a positive impact on the Union's shift towards 'greener' energy consumption. ${ }^{72}$

The economic development in the north, and specific measures to support the northern counties, has caused problems in Norway's relationship with the EU. In particular, as the Commission revised their state aid regulation (as normal for every 7-year framework period) in 2013 for the 2014-2020 cycle, the whole scheme of differentiated employer's tax came into question. ${ }^{73}$ The Commission had a desire to streamline and reduce various state aid regimes in regions and sectors where aid was deemed unnecessary, throughout the EEA. ${ }^{74}$ Although this streamlining was not targeted in the Norwegian Arctic at all, the fact that Norway adheres to the EEA-regime, while also stimulating its own Arctic areas, led to a clash with the new EU-regulatory regime. Again, Norwegian media and politicians blamed the $\mathrm{EU}$ for meddling in domestic tax regimes. ${ }^{75}$ For the north Norwegian counties, this entailed a loss of regional support mechanisms. In 2013, the amount of exempted fees totalled 13 billion NOK (approximately €1.4 billion), where a majority went to support North Norway specifically. ${ }^{76}$ Dialogue between north Norwegian actors and the EU is still continuing, as the Arctic environment and related challenges are being used to argue for special exemptions. ${ }^{77}$

72 Runa Haug Khoury and others, 'Environmental Considerations in the Arctic: Sustainable Resource Exploitation' (Bellona Foundation 2015) <http://network.bellona.org/content/ uploads/sites/2/2016/o1/Arktisrapport-versjon-2.0_web.pdf> accessed 1 March 2016; Andreas Raspotnik, 'Renewable Energy Production in the Norwegian Arctic: An Energy Boost for Europe?' High North News (11 January 2016) <http://www.highnorthnews.com/ renewable-energy-production-in-the-norwegian-arctic-an-energy-boost-for-europe/> accessed 1 March 2016.

73 Torjus Kandal, 'Kan Være Smutthull I Differensiert Arbeidsgiveravgift' (Nordland Fylkeskommune, 17 December 2014) <http://www.nfk.no/artikkel.aspx?Aid=43402\&Back=1> accessed 1 March 2016.

74 Norwegian Government, 'Spørsmål Og Svar-Differensiert Arbeidsgiveravgift' (6 June 2014） <https://www.regjeringen.no/no/tema/okonomi-og-budsjett/skatter-og-avgifter/ Differensiert-arbeidsgiveravgift/Sporsmal-og-svar---differensiert-arbeidsgiveravgift/ id762193/> accessed 1 March 2016.

75 Lars Wiker, 'Regjeringen Ber EU Snu Om Arbeidsgiveravgift' Nationen (30 April 2014) <http://www.nationen.no/eu/regjeringen-ber-eu-snu-om-arbeidsgiveravgift/> accessed 1 March 2016.

76 Norwegian Government.

77 Hege Eilertsen, 'EU-Politikere Skal Turnere Nord-Norge' High North News (13 February 2015) <http://www.highnorthnews.com/eu-politikere-skal-turnere-nord-norge-til-uka/> accessed 1 March 2016. 
Another aspect of the EU's Arctic engagement in Norway concerns the Union's relationship with the indigenous Sami population. The traditional lands of the Sámi people in Norway—Sápmi—stretch from Hedmark county in the middle of Norway, to the Russian border in the north. Most Sámi live in North Norway. Reindeer herding and other traditional Sámi livelihoods, such as fishing, hunting and gathering, are some of the most important preservers of the Sámi cultural heritage. These lands are increasingly under pressure, as, for example, mining companies are investing in the north. The Union's legal engagement with indigenous peoples issues in the Arctic covers a broad variety of policies, e.g. development, trade, animal welfare, environment, education and culture, regional policy or general human rights. However, only a few legal acts apply directly, as for instance Regulation 1007/2009 on trading of seal products. ${ }^{78}$ This Regulation, ${ }^{79}$ although it does not have a direct impact on Sami in North Norway, serves as prime example for the EU's impact in the Arctic, despite the exclusion of the EU from the region's main governance table. Both Canada and Norway challenged the regulation and brought the case before the World Trade Organization (WTO) in 2009. The wTO upheld the ban in 2014, with two exceptions needing clarification. Accordingly, the regulation was brought into compliance with wTO regulations in October 2015. ${ }^{80}$

The Commission has been aware of the discrepancies between EU institutions and Arctic indigenous peoples and hosted four events as part of an 'Arctic EU-Indigenous Dialogue' between 2010 and 2014. Stępień critically remarked that initially these meetings often lacked continuity and that they were only being used by EU officials to highlight the Union's project with relevance for the Arctic indigenous community. ${ }^{81}$

78 Timo Koivurova and others, 'EU Competencies Affecting the Arctic' (Directorate-General for External Policies, European Parliament 2010) EP/EXPO/B/AFET/FWC/2009-01/LOT2/ 0437-39<http://www.europarl.europa.eu/RegData/etudes/etudes/join/2010/433793/EXPOAFET_ET(2010)433793_EN.pdf> accessed 28 November 2015.

79 Ibid.

8o Council of the European Union, 'Seal Products Trade: The EU Ban Adapted to WTO Rules' (Press Release (69o/15), 1 October 2015) < http://www.consilium.europa.eu/en/press/pressreleases/2015/10/o1-seal-products/> accessed 2 October 2015; Nikolas Sellheim, 'The Goals of the EU Seal Products Trade Regulation: From Effectiveness to Consequence' (2015) 51(3) Polar Record 274; Nikolas Sellheim, 'Policies and Influence: Tracing and Locating the EU Seal Products Trade Regulation' (2015) 17(1) International Community Law Review 3.

81 Adam Stępień, 'Internal Contradictions and External Anxieties: One "Coherent" Arctic Policy for the European Union?' in Gudmundur Alfredsson, Timo Koivurova and Ju Jabour (eds), The Yearbook of Polar Law Volume 7 (Martinus Nijhoff Publishers 2015) 260. 
This Chapter has examined the Arctic relationship between Norway and the EU in the light of three examples, namely (1) the discussions embedded in the Arctic governance theme, (2) the EU's impact on, and efforts to regulate, industrial policies of relevance to the Norwegian Arctic, and finally (3) regional development and indigenous peoples. We asked: what can help to explain the ambivalent stance taken by Norway towards the Union, concerning the EU's Arctic engagement?

In general, the EEA agreement, which is the legal backbone of Norway's close association with the Union, affects the relationship between the Scandinavian country and the EU in the (Norwegian) Arctic. This Chapter has demonstrated that the Eu's manifold Arctic endeavours hold a distinct regional element in Norway. With academic and public focus often centred around the debate about the EU's AC observer status bid and the seal product issue between Canada and the EU, we argue that this limited conception hinders a greater understanding of the EU's role in the north in general and its relationship with Norway in particular. Despite disagreements on matters such as the ban on seal products, Norway has continuously supported the Union's bid for AC observer status. ${ }^{82}$ Moreover, Norway welcomes an increasing EU Arctic engagement. Despite Norway's inability to directly impinge upon the Union's Arctic policy, it holds many levers to influence and shape it.

Norway's relationship with the EU in the Norwegian Arctic must be understood as a continuation of its larger EU-policy, where the balance between separation and further integration is crucial. The Arctic has become yet another avenue for dialogue and cooperation with Brussels, in which both companies and the regional governments of North Norway can assert more influence. The region as an overall policy field has created venues to increase policy coordination in areas such as regional development, research and industrial endeavours, though in turn it depends on to what extent the EU-system and Norwegian actors choose to utilise such coordination. Norway is likely, in any case, to remain the Eu's staunchest ally in its Arctic engagement. Geography,

82 Njord Wegge, 'Politics between Science, Law and Sentiments: Explaining the European Union's Ban on Trade in Seal Products' (2013) 22(2) Environmental Politics 255; Adele Airoldi, 'The European Union and the Arctic Region: Developments and Perspectives 2010-2014' (Nordic Council of Ministers 2014) TemaNord 2014:565 $30<$ http://norden .diva-portal.org/smash/get/diva2:771155/FULLTEXTo1.pdf> accessed 2 March 2015. 
historic ties, and economic and cultural integration are cornerstones of this relationship with the Scandinavian country holding many resource potentials that the EU needs, such as hydrocarbons and renewables.

At the same time, Norway is challenged by the way the Eu's various actions are perceived and described in the general debate. A lack of understanding with regards to the complex institutional system and tendencies to scapegoat Brussels for undesirable policy outcomes are fallacies across the EU Member States. This might pose an additional challenge for Norway's relations with the EU in the Arctic, as various Norwegian governments continue to support the EU's northern endeavour, while at the same time portraying EU policies and debate as a threat to Norwegian interests. Such a paradox is only likely to complicate matters for all parties.

For the EU, the Arctic as a region, both from the regional as well as circumpolar perspective, has relatively low priority. While both the Eastern Neighbourhood (for example through the Ukraine crisis) and the Southern Neighbourhood (for example, as a result of the migration crisis) may lead to a step backwards in the Union's supranational integration efforts, the Norwegian Arctic would not have the same impact on the EU's neighbourhood policy. ${ }^{83}$ This is a somewhat insurmountable detail Norwegian policy-makers are fully aware of. ${ }^{84}$

Moreover, up to the present, the Union has not yet found its very own Arctic narrative - a broad concept or single organising idea similar to the Northern Dimension or the Barcelona Process that eventually offers a substantive and EU-unique approach to Arctic matters. ${ }^{85}$ Likewise, the EU's Arctic policy engagement has so far also lacked sharpness by not comprehensively taking into account the various Arctics of the circumpolar north and their different challenges. While the EU takes a back seat in circumpolar Arctic affairs, it is a key player in the European Arctic, with its regulatory competences, financial contributions and social impacts going beyond its Arctic Member States,

83 Adam Stępień and Andreas Raspotnik, 'Exploring Reasons \& Remedies for the EU's Incapability to Devise an "Arctic Policy": The Quest for Coherence' in Lassi Heininen, Heather Exner-Pirot and Joël Plouffe (eds), Arctic Yearbook 2015 (Northern Research Forum 2015) 434.

84 Interview conducted by Andreas Raspotnik with two representatives from the Norwegian MFA working on Arctic matters in Oslo on 24 April 2014.

85 The Barcelona Process, launched in 1995, formed the basis of the Euro-Mediterranean partnership to manage the relationship between the EU and its Mediterranean neighbours and eventually evolved in the Union for the Mediterranean, see <http://eeas .europa.eu/euromed/barcelona_en.htm> accessed 20 November 2016. 
Finland and Sweden. ${ }^{86}$ Hence, the EU is not simply an 'Arctic user', attracted by the region's various changes, challenges and/or opportunities, that can publically be equated with 'non-Arctic' States. However, neither Norway nor the EU have yet found a coherent way to turn these steps to positive action.

86 Adam Stępien, 'The EU Needs a Two-Tier Approach towards the Arctic: A General Policy for the Circumpolar Arctic and a Concrete Strategy for the European Arctic' (The Arctic Institute, 10 December 2015) <http://www.thearcticinstitute.org/eu-needs-two-tier-approachtowards-the-arctic/> accessed 11 December 2015 . 